\title{
Review \\ Importance of Cx43 for Right Ventricular Function
}

\author{
Kerstin Boengler *, Susanne Rohrbach (D), Norbert Weissmann ${ }^{\dagger}$ and Rainer Schulz (1) \\ Institute of Physiology, Justus-Liebig University, 35392 Giessen, Germany; \\ susanne.rohrbach@physiologie.med.uni-giessen.de (S.R.); norbert.weissmann@innere.med.uni-giessen.de (N.W.); \\ rainer.schulz@physiologie.med.uni-giessen.de (R.S.) \\ * Correspondence: kerstin.boengler@physiologie.med.uni-giessen.de; Tel.: +49-641-99-47343; \\ Fax: +49-641-99-47239 \\ † Excellence Cluster Cardiopulmonary System, Universities of Giessen and Marburg Lung Center (UGMLC), \\ Member of the German Center for Lung Research (DZL), Justus Liebig University of Giessen, Aulweg 130, \\ 35392 Giessen, Germany.
}

check for updates

Citation: Boengler, K.; Rohrbach, S.; Weissmann, N.; Schulz, R. Importance of Cx43 for Right Ventricular Function. Int. J. Mol. Sci. 2021, 22, 987. https://doi.org/10.3390/ ijms22030987

Academic Editor: Georg R. Zoidl Received: 21 December 2020

Accepted: 18 January 2021

Published: 20 January 2021

Publisher's Note: MDPI stays neutral with regard to jurisdictional claims in published maps and institutional affiliations.

Copyright: (c) 2021 by the authors. Licensee MDPI, Basel, Switzerland. This article is an open access article distributed under the terms and conditions of the Creative Commons Attribution (CC BY) license (https:// creativecommons.org/licenses/by/ $4.0 /)$.
Abstract: In the heart, connexins form gap junctions, hemichannels, and are also present within mitochondria, with connexin 43 (Cx43) being the most prominent connexin in the ventricles. Whereas the role of $\mathrm{Cx} 43$ is well established for the healthy and diseased left ventricle, less is known about the importance of $\mathrm{Cx} 43$ for the development of right ventricular (RV) dysfunction. The present article focusses on the importance of $\mathrm{Cx} 43$ for the developing heart. Furthermore, we discuss the expression and localization of Cx43 in the diseased RV, i.e., in the tetralogy of Fallot and in pulmonary hypertension, in which the RV is affected, and RV hypertrophy and failure occur. We will also introduce other Cx molecules that are expressed in RV and surrounding tissues and have been reported to be involved in RV pathophysiology. Finally, we highlight therapeutic strategies aiming to improve RV function in pulmonary hypertension that are associated with alterations of Cx43 expression and function.

Keywords: connexin; right ventricle; pulmonary hypertension; tetralogy of fallot; mitochondria

\section{Structure of Connexin Proteins and Expression in the Heart}

Connexins are a family of transmembrane proteins, which are labelled according to their molecular weight. The human family comprises 21 members with molecular weights between 26 and $60 \mathrm{kDa}$. Of the connexin protein family, connexin 43 (Cx43) has a broad expression spectrum in cells and organs and is the most studied isoform. Therefore, the present review focusses mainly on the role of $\mathrm{Cx} 43$.

The connexin proteins share a similar structure, i.e., an aminoterminus located in the cytosol, two extracellular loops, one intracellular loop and four transmembrane domains. The carboxyterminus, which varies in length between the connexin proteins, is also present in the cytosol. The major role of connexins is the formation of gap junctions, which facilitate the exchange of factors weighing up to $1.5 \mathrm{kDa}$ and thereby mediate electrical and metabolic cell-cell coupling. Such gap junctions are formed by two opposing connexons, each from one cell. The connexon-or hemichannel-itself is composed of six connexin proteins. Whereas the unpaired hemichannels in the plasma membrane remain closed under physiological conditions [1], pathological situations favor their opening, a process leading to dissipation of ionic gradients across the plasma membrane and finally to cell death [2,3]. In addition, Cx43-formed hemichannels may also open upon activation of ryanodine receptors [4]. Cell-cell communication is not only mediated by gap junctions, but is also achieved via extracellular vesicles, in which $\mathrm{Cx} 43$ has been detected [5]. Myocardial ischemia/reperfusion injury impairs the secretion of $\mathrm{Cx} 43$ into cardiomyocyte-derived extracellular vesicles [6]. In addition to the plasma membrane, $C \times 43$ is localized at the inner membrane of mitochondria isolated from ventricular myocardium, specifically in 
subsarcolemmal mitochondria (SSM) $[7,8]$. Cx43, which is encoded in the nucleus, is imported into the SSM in an Hsp90 (heat shock protein 90)/TOM (translocase of the outer membrane)-dependent pathway [9]. Only limited amounts of Cx43 are detected within interfibrillar mitochondria (IFM), which differ from the subsarcolemmal mitochondria in terms of respiration and calcium handling [10,11]. The mechanism responsible for the higher amount of Cx43 in SSM than in IFM is yet unclear.

Several aspects of mitochondrial function are influenced by Cx43, e.g., respiration [12], formation of reactive oxygen species (ROS) [13,14], opening of the mitochondrial permeability transition pore [15] and potassium handling [16]. An aminoterminally truncated Cx43-isoform (Gja1-20k, size $20 \mathrm{kDa}$ ) generated by alternative translation is important for the transport of the full-length protein to the plasma membrane and the normal electrical function of the heart $[17,18]$. Moreover, Gja1-20k is also present in myocardial SSM but not in IFM [19]. The overexpression of Gja1-20k decreases angiotensin II-induced hypertrophy, enhances mitochondrial oxygen consumption and lowers ROS formation [20]. In contrast, the truncated Cx43 isoform Gja1-11k (size $11 \mathrm{kDa}$ ) preferentially localizes to the nucleus and limits the progression of the cell cycle [21]. Therefore, the function of Cx43 is not restricted to its classical role as a gap junction protein.

The carboxyterminus of $\mathrm{Cx} 43$ contains several amino acids, which can be phosphorylated by different kinases, among them protein kinase $C$ (PKC), mitogen-activated MAP kinase (MAPK), casein kinase 1 or protein kinase B (AKT) (for review see [22]). The phosphorylation of $\mathrm{Cx} 43$ regulates the size of gap junctions as well as cell-cell communication. Moreover, phosphorylation of $\mathrm{Cx} 43$ seems to be involved in the release of exosomes [23]. In addition, mitochondrial Cx43 is phosphorylated [24]; however, the exact contribution of phosphorylation towards the function of mitochondrial Cx43 is not yet resolved. Gap junctional intercellular communication is also regulated by connexin ubiquitination [25] and by protein-protein interactions [26].

Connexin proteins have been detected in a variety of different organs and cells. In the heart, $\mathrm{Cx} 43$ is the most abundantly expressed isoform and is localized in ventricular and atrial cardiomyocytes, but also in endothelial cells, smooth muscle cells and fibroblasts. $\mathrm{Cx} 40$ is predominantly expressed in atrial cardiomyocytes, in the cardiac conduction system and is also found in endothelial cells. Endothelial cells also express Cx37.

Table 1 summarizes the localization of $\mathrm{Cx} 37, \mathrm{C} \times 40$ and $\mathrm{Cx} 43$ in cardiac compartments or cell types.

Table 1. Localization of connexins in the heart.

\begin{tabular}{ccc}
\hline Connexin & Localization & Reference \\
\hline \multirow{2}{*}{ Cx37 } & Vascular endothelial cells, endothelial & cells of the endocardium \\
& Vascular endothelial cells & {$[27]$} \\
\hline & Fibroblasts & {$[27]$} \\
Cx40 & Atria & {$[28]$} \\
& Smooth muscle cells & {$[27,29]$} \\
& His bundle & {$[30]$} \\
& Bundle branches & {$[31]$} \\
& Distal Purkinje system & {$[32]$} \\
& Atria & {$[33]$} \\
\hline & Fibroblasts & {$[27,29]$} \\
& Smooth muscle cells & {$[28]$} \\
& His bundle & {$[30]$} \\
& Distal Purkinje system & {$[31]$} \\
& Ventricles & {$[33]$} \\
& & {$[29]$} \\
\hline
\end{tabular}


The comparison of the amount of Cx43 in the right ventricle (RV) and left ventricle (LV) shows no difference in mouse [34,35], rat [36,37], or human myocardium [29], and similar protein levels are also described for right and left human atria [29].

When analyzing the amount of $\mathrm{C} \times 43$ in total protein extracts from right and left mouse ventricular tissue and also in SSM isolated from mouse RV and LV tissue (Figure 1), comparable amounts of $\mathrm{Cx} 43$ in total RV and LV protein extracts were detected. Only marginal Cx43 amounts were found in IFM confirming previous data from our and other groups $[8,38,39]$. These limited amounts of $\mathrm{C} \times 43$ within IFM were similar between IFM isolated from RV and LV myocardium.
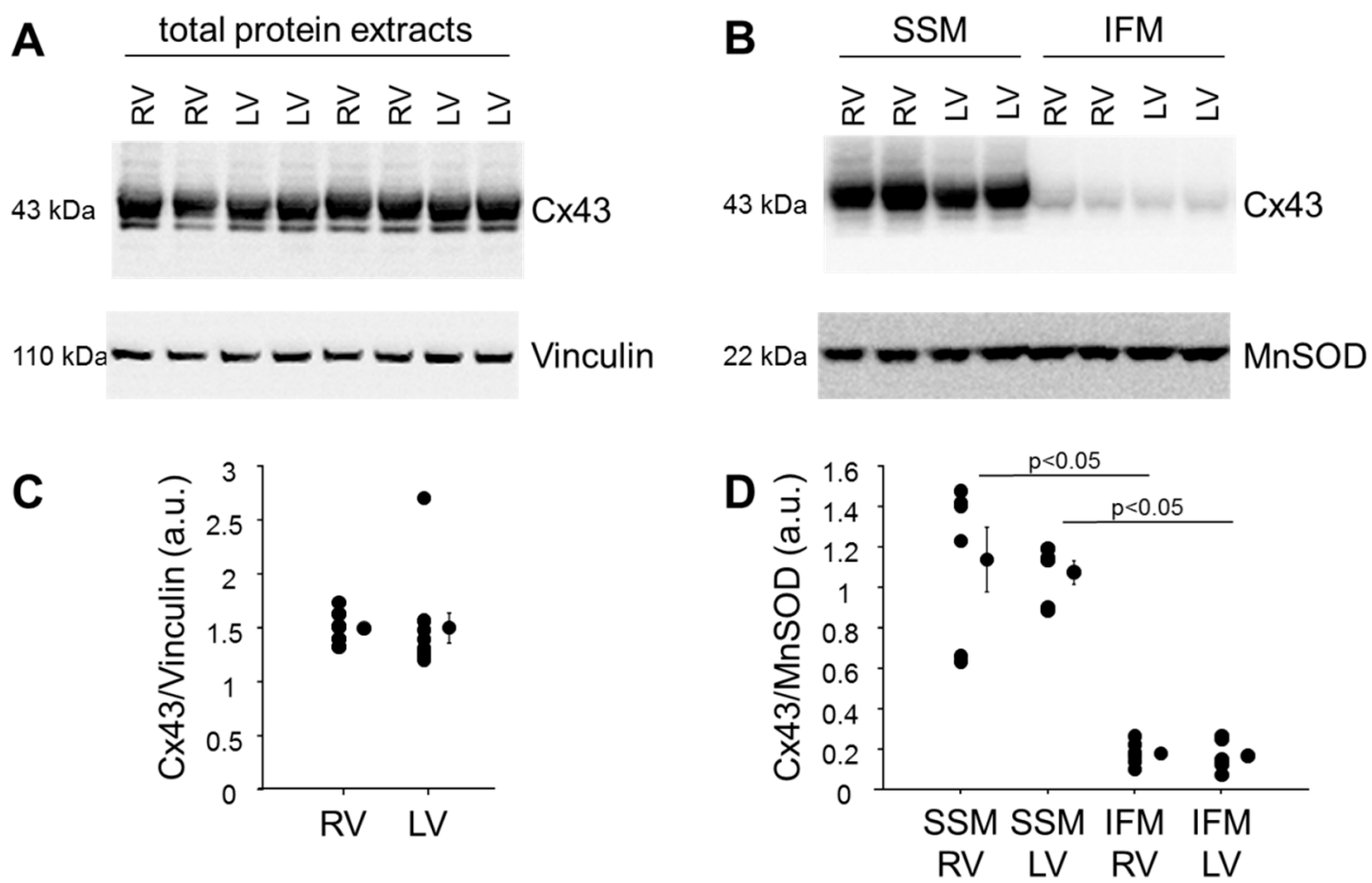

Figure 1. Amount of Cx43 in left and right ventricular total and mitochondrial protein extracts. Western blot analysis was performed for Cx43, Vinculin (housekeeping protein used for total protein extracts) and MnSOD (manganese superoxide dismutase-housekeeping protein used for mitochondrial protein extracts) on proteins isolated from right and left mouse (C57Bl6/J) ventricular tissue (A) or on subsarcolemmal (SSM) and interfibrillar (IFM) mitochondrial proteins, isolated from mouse right (RV) and left (LV) ventricular tissue (B). A and B demonstrate uncut, representative parts of the Western Blot analysis. The amounts of $C \times 43$ were normalized to $\operatorname{Vinculin}(\mathbf{C}, n=10)$ or $\operatorname{MnSOD}(\mathbf{D}, \mathrm{n}=6)$. The purity of the mitochondrial preparations was demonstrated by the absence of marker proteins for other cellular compartments (plasma membrane, cytosol and nucleus, Supplementary Materials Figure S1). Data were compared by unpaired Student's t-test (total proteins) or by two-way ANOVA (mitochondrial proteins). The study was approved by the animal welfare office of the Justus-Liebig University, Giessen, Germany (522_M, approved 29 November 2019).

In contrast, $\mathrm{Cx} 40$ is more abundantly detected in right than in left human atria, whereas similar transcript and protein levels are found in human right and left ventricles [29,40].

In summary, $\mathrm{Cx} 43$ is the most studied member of the connexin family. Whereas the classical role of $\mathrm{Cx} 43$ is the formation of gap junctions and hemichannels at the plasma membrane, recent studies demonstrate a broader spectrum of $\mathrm{C} \times 43$ localizations, i.e., within exosomes and mitochondria, and also truncated $\mathrm{Cx} 43$ isoforms reveal specific functions. In the heart, Cx43 is evenly distributed within ventricles, atria and ventricular mitochondria.

\section{Role of $\mathrm{Cx} 43$ for the Developing Heart}

The contribution of Cx43 towards the development of the heart is studied in different strains of knockout mice as well as in Cx43-overexpressing mice. Homozygous Cx43-deficient mice, in which nearly the whole coding sequence (including the sequences 
encoding the transmembrane domains) is replaced by the neo ${ }^{\mathrm{r}}$ gene (neomycin resistance gene), die shortly after birth from failing pulmonary gas exchange [41]. Despite the fact that $\mathrm{C} \times 43$ is expressed in several different organs, only the heart shows abnormal morphologies starting at embryonic day ten with abnormal looping [42]. The analysis of the homozygous Cx43-deficient mice reveals that the conus region overlying the RV outflow tract is enlarged, and double pouches are observed at the base of the pulmonary outflow tract [43]. The RV outflow tract is filled with intraventricular septa and thus the RV outflow tract is blocked. In addition, mice with a $\mathrm{C} x 43 / \beta$-galactosidase fusion protein with dominant negative effects on cell-cell communication reveal malformations of the RV outflow tract and outflow tract obstruction [44]. Abnormal RV outflow tract bulging, trabecular in-growth, and extravasation of contrast material into the RV wall are shown in inducible Cx43-knockout mice using magnetic resonance imaging [45]. The analysis of the expression of $\mathrm{Cx} 43$ in rabbit hearts demonstrates a heterogeneous expression of the protein in the RV outflow tract and shows that cells are connected at their lateral sides [46]. Despite the high expression level of $\mathrm{Cx} 43$ in the left ventricle, no morphological alterations are described in this heart chamber; however, patterning defects of the coronary arteries are also observed [47]. Mice constitutively overexpressing Cx43 are generally viable and fertile; however, postnatal viability is reduced [48]. Interestingly, mice overexpressing Cx43 exhibit a similar phenotype as Cx43-knockout mice. Here, also an enlargement of the conotruncal region of the RV and narrowing of the pulmonary outflow region is observed [48]. The effects of $\mathrm{Cx} 43$ on heart morphology seem to be mediated by cardiac neural crest cells and in the non-crest neural tube [49].

The analysis of hearts from Cx40-knockout mice shows a 33\% incidence of doubleoutlet right ventricle/tetralogy of Fallot (TOF) [50] and also the occurrence of a septum primum defect and ventricular septal defects [51]. Therefore, as well as Cx43, Cx40 seems to play a role in cardiogenesis, especially in the septation process (for review see [52].

Taken together, despite a high expression of $\mathrm{C} \times 43$ in the left heart, data from Cx43deficient, as well as Cx43-overexpressing, mice emphasize the role of Cx43 in the RV outflow tract development. The reason for a similar phenotype in both Cx43-deficient and $\mathrm{C} \times 43$-overexpressing mice is unclear at present. Since the expression of $\mathrm{Cx} 40$ is unaffected by deletion of Cx43 [41,42], a compensation for the loss of Cx43 function by Cx40 is unlikely; however, mice in which $\mathrm{Cx} 43$ is replaced by $\mathrm{Cx} 40$ are rescued from postnatal lethality [53] indicating that the two proteins share at least some important functions.

\section{Connexins in the Diseased Right Ventricle}

\subsection{Tetralogy of Fallot}

TOF is the most common cyanotic congenital heart disease and is characterized by ventricular septal defect, obstruction of the right ventricular outflow tract, right ventricular hypertrophy and an over-riding aorta. Whereas the pathomechanisms of TOF are not completely understood up to now, a contribution of Cx43 is suggested. Increased amounts of Cx43 mRNA and protein are detected in the RV outflow tract of children with TOF compared to healthy controls [54], while others describe lower amounts of Cx43 protein in children with TOF compared to those with ventricular septal defect [55]. Data on the distribution of $\mathrm{Cx} 43$ at the plasma membrane showed either an enhanced heterogeneous localization of Cx43 in TOF patients [54] or no differences in the amount of Cx43 at the polar compared to the lateral sides of the cardiomyocytes-and also no alterations of Cx43 phosphorylation-between TOF patients and patients with other cardiac malformations [56]. Histone $\mathrm{H} 3$ containing the acetylated lysine 18 (H3K18ac) is shown to directly bind to the Cx43 promoter, and the acetylation of H3K18ac is reduced in patients with TOF, which may alter the transcription and subsequently the protein amount of $\mathrm{Cx} 43$ [57]. Whereas a point mutation within the Cx43 promoter increases the susceptibility to TOF [57], others found no causal role of single nucleotide polymorphisms within the $\mathrm{C} \times 43$ gene for the development of TOF [56] and consider Cx43 mutations not as important contributors in the development of outflow tract abnormalities [58]. 
In accordance with the phenotype of Cx40 mice, mutations in the GJA5 gene encoding Cx40 are considered a susceptibility gene for TOF [59].

Patients with corrected TOF have a higher risk of developing arrhythmias and dying due to sudden cardiac death. In a porcine model of repaired TOF, the remodeling of RV conduction and the repolarization properties are associated with a decreased $\mathrm{Cx} 43$ protein expression, as well as enhanced lateralization of the protein [60]. A trend towards increased Cx43 lateralization after repaired TOF is also observed in the piglet LV [61]. In addition, a reduced amount of the Cx43 mRNA occurs one year after TOF repair in dogs, although the Cx40 mRNA level is not altered [62].

Table 2 summarizes studies addressing the role of connexins in TOF and repaired TOF.

Table 2. Connexins in tetralogy of Fallot.

\begin{tabular}{|c|c|c|c|}
\hline Species & Model & Result & Reference \\
\hline Human & $\begin{array}{l}\text { TOF patients }(1.3 \pm 0.9 \text { years }) \text { and normal } \\
\text { controls }(1.8 \pm 0.9 \text { years })\end{array}$ & TOF: Cx43 mRNA $\uparrow$ & {$[54]$} \\
\hline Human & $\begin{array}{l}\text { TOF patients }(4.6 \pm 0.9 \text { months }) \\
\text { Control: patients with ventricular septal } \\
\text { defect, without RVOT pathology } \\
(3 \mathrm{w}-4.5 \text { months })\end{array}$ & $\begin{array}{l}\text { TOF: Cx43 protein } \downarrow \\
\text { Cx43 irregularly distributed on the } \\
\text { cardiomyocyte surface }\end{array}$ & [55] \\
\hline Human & $\begin{array}{l}\text { TOF patients ( } 0-2 \text { years, }>2 \text { years) } \\
\text { Control: age-matched patients with } \\
\text { pulmonary atresia with or without } \\
\text { ventricular septal defects, double chamber } \\
\text { RV or truncus arteriosus communis }\end{array}$ & $\begin{array}{l}\text { TOF: no alteration of } \mathrm{C} \times 43 \text { distribution } \\
\text { and phosphorylation; } \\
\text { Point mutations within the } \mathrm{C} \times 43 \text { gene no } \\
\text { cause for TOF development }\end{array}$ & {$[56]$} \\
\hline Human & $\begin{array}{l}\text { TOF patients (median age: } 7.5 \text { months) } \\
\text { Normal controls: (median age: } 48 \text { months) }\end{array}$ & TOF: H3K18ac acetylation $\downarrow$ & [57] \\
\hline Human & TOF patients (median age: 7.5 months & $\begin{array}{l}\text { SNP in the Cx43 promoter is associated } \\
\text { with } \downarrow \text { Cx43 mRNA }\end{array}$ & [57] \\
\hline Pig & rTOF or sham surgery, $23 \pm 1 \mathrm{w}$ after surgery & $\begin{array}{l}\text { rTOF: remodeling of } \mathrm{RV} \text { conduction and } \\
\text { repolarization properties; } \\
\text { Cx43 protein } \downarrow \text { in epi- not in endocardium; } \\
\text { Cx43 lateralization } \uparrow \text { endocardium }\end{array}$ & {$[60]$} \\
\hline Pig & rTOF or sham surgery, $23 \pm 1 \mathrm{w}$ after surgery & $\begin{array}{l}\text { rTOF: } \mathrm{LV} \text { tissue: trend towards } \uparrow \mathrm{Cx} 43 \\
\text { lateralization, } \mathrm{C} \times 43 \text { protein unchanged }\end{array}$ & {$[61]$} \\
\hline Dog & $\begin{array}{l}\text { rTOF or no surgery, } \\
1 \text { year after surgery }\end{array}$ & $\begin{array}{l}\text { rTOF: RVOT: Cx43 mRNA } \downarrow, \text { Cx40 } \\
\text { mRNA unchanged }\end{array}$ & {$[62]$} \\
\hline Human & $\begin{array}{l}300 \text { patients with congenital heart dis ease, } \\
\text { including } 224 \text { with outflow tract anomalies, } \\
152 \text { with TOF, } 50 \% \text { of the cohort }<1 \text { year } \\
\text { of age }\end{array}$ & $\begin{array}{l}\text { In patients with congenital heart disease: } \\
\text { no amino acid changing mutations in the } \\
\text { gene encoding Cx43 }\end{array}$ & {$[58]$} \\
\hline
\end{tabular}

LV: left ventricle; rTOF: repaired tetralogy of Fallot; RV: right ventricle; RVOT: right ventricular outflow tract; TOF: tetralogy of Fallot; $\uparrow$ : increased; $\downarrow$ : decreased.

Taken together, whereas a contribution of both $\mathrm{Cx} 40$ and $\mathrm{C} \times 43$ towards the development of TOF is suggested, the exact mechanisms by which the proteins are involved in the disease remain elusive.

\subsection{Pulmonary Hypertension: Connexins in Vascular Cells}

Exposure to hypoxia leads to pulmonary vasoconstriction and, consequently, an increase in pulmonary arterial pressure occurs, which is characteristic for pulmonary hypertension $(\mathrm{PH})$. The increase in pulmonary arterial pressure is sustained due to subsequent remodeling of the pulmonary vasculature. Pulmonary arterial smooth muscle cells show enhanced proliferation and decreased apoptosis. 
In order to study molecular mechanisms regulating the development of $\mathrm{PH}$, several animal models are studied. The most widely used model is the rat monocrotaline-model, in which upon a single injection of monocrotaline, a pyrrolizidine alkaloid, the animals develop PH with severe remodeling of the pulmonary vasculature and RV hypertrophy approximately within four weeks [63]. This model represents severe $\mathrm{PH}$ as it occurs in idiopathic pulmonary arterial hypertension (IPAH) in men. The chronic hypoxia model is also frequently studied and results in PH. In contrast to the monocrotaline model, where the intima of the vessels is also largely affected, chronic hypoxia leads to less severe $\mathrm{PH}$ with vessel media thickening and thus represents so-called group $3 \mathrm{PH}$. Another approach to induce PH uses the vascular endothelial growth factor receptor antagonist Sugen 5416 in combination with chronic hypoxia. In rats, this treatment causes angio-obliterative lesions in the pulmonary arterioles, which resemble the "plexiform" lesions found in patients with $\mathrm{IPAH}$, and thus also induces a severe form of $\mathrm{PH}$ [64]. In contrast to the aforementioned methods, banding of the pulmonary artery (PAB) increases RV pressure without affecting and being dependent on the pulmonary vasculature. Animal models of PH are reviewed elsewhere $[65,66]$.

A contribution of connexins towards the development of $\mathrm{PH}$ is investigated in vascular cells from animal models as well as in cells isolated from patients with PH. In pulmonary arterial endothelial cells isolated from explanted lungs of $\mathrm{PH}$ patients, reduced amounts of both Cx37 and Cx40 are detected [67]. However, others report no differential Cx37 and $\mathrm{C} \times 40 \mathrm{mRNA}$ and protein expression in pulmonary arteries of monocrotaline-treated rats or rats exposed to chronic hypoxia [68]. The use of the phosphodiesterase 5 inhibitor sildenafil, which elevates intracellular amounts of cGMP and supports vasodilation, leads to an upregulation of $\mathrm{Cx} 40$ in pulmonary arterial smooth muscle cells from monocrotalinetreated rats and decreases cell proliferation. In the presence of LDN-193189, an antagonist of type II receptor for bone morphogenetic protein (BMPR2), sildenafil fails to stimulate the amount of $\mathrm{Cx} 40$ in pulmonary arterial smooth muscle cells from monocrotaline-treated rats, thereby showing the importance of BMPR2 in triggering the sildenafil-induced expression of Cx40 [69].

The expression of $\mathrm{Cx} 43$ is studied in different forms of $\mathrm{PH}$ and it is shown to decrease in pulmonary arteries isolated from patients with idiopathic $\mathrm{PH}$ [70]. Those patients exhibit enhanced levels of micro-RNA1 (miR-1), and the transduction of pulmonary arterial smooth muscle cells with miR-1 induces a downregulation of the Cx43 expression [71]. In contrast to the decreased $\mathrm{Cx} 43$ level in patients with IPAH, enhanced amounts of $\mathrm{Cx} 43$ are detected in pulmonary arteries derived from patients with chronic hypoxia-induced $\mathrm{PH}$ [70]. In pulmonary arteries of rats exposed to chronic hypoxia, the Cx43 mRNA—in contrast to the $\mathrm{C} \times 37$ or $\mathrm{C} \times 40 \mathrm{mRNA}$-is upregulated [68]. An enhanced Cx43 protein amount is also shown in lungs of Sugen 5416/hypoxia-treated rats, an effect dependent on the activation of ASK-1 (apoptosis signal-regulating kinase-1), an upstream regulator of the mitogenactivated protein kinase pathway [72]. A causal role of $\mathrm{C} \times 43$ for the development of $\mathrm{PH}$ is demonstrated in heterozygous Cx43-deficient mice subjected to chronic hypoxia that were partially protected against $\mathrm{PH}$ [70]. Data on connexins in the vasculature in different models of $\mathrm{PH}$ are presented in Table 3.

In summary, connexin expression is influenced by $\mathrm{PH}$ in vascular cells. $\mathrm{Cx} 40$ is downregulated in $\mathrm{PH}$ in humans and its stimulation seems to be involved in mediating the protective effects of sildenafil. In contrast, the amount of $\mathrm{Cx} 43$ can be either up- or downregulated depending on the exact form of $\mathrm{PH}$ and this has to be taken into account when considering $\mathrm{Cx} 43$ as a vascular target for the treatment of $\mathrm{PH}$. 
Table 3. Pulmonary hypertension: connexins in vascular cells.

\begin{tabular}{|c|c|c|c|}
\hline Species & Model & Result & Reference \\
\hline Human & $\begin{array}{l}\text { PAECs from PH patients and control } \\
\text { donor lungs }\end{array}$ & PH: Cx37 and Cx40 mRNA $\downarrow$ & [67] \\
\hline Rat & $\begin{array}{l}\text { Chronic hypoxia for } 3 \mathrm{w} \\
\text { MCT }(60 \mathrm{mg} / \mathrm{kg}), 4 \mathrm{w} \text {, isolation of } \\
\text { intra-pulmonary arteries }\end{array}$ & $\begin{array}{l}\text { Chronic hypoxia, MCT: no alteration of } \\
\text { Cx37, Cx40 mRNA and protein } \\
\text { Chronic hypoxia: Cx43: } \uparrow \text { mRNA and } \\
\text { protein } \\
\text { MCT: Cx43 unchanged }\end{array}$ & [68] \\
\hline Rat & $\begin{array}{l}\text { MCT }(60 \mathrm{mg} / \mathrm{kg}) \text { or vehicle, isolation of } \\
\text { PASMC after } 28 \mathrm{~d} \text {, treatment of cells with } \\
\text { sildenafil or sildenafil + LDN-193189 }\end{array}$ & $\begin{array}{l}\text { PH: sildenafil } \uparrow C \times 40 \mathrm{mRNA} \text { and protein } \\
\text { in PASMC, effect reversed by } \\
\text { LDN-193189 }\end{array}$ & [69] \\
\hline Human & $\begin{array}{l}\text { Patients with IPAH or PH due to } \\
\text { hypoxemic chronic lung disease }\end{array}$ & $\begin{array}{l}\text { iPH: Cx43 } \downarrow \\
\text { CH-PH: Cx43个 }\end{array}$ & [70] \\
\hline Mouse & $\begin{array}{l}\mathrm{C} \times 43^{+/+} \text {and } \mathrm{C} \times 43^{+/-} \text {mice undergoing } \\
\text { hypoxia-induced } \mathrm{PH}\end{array}$ & $\begin{array}{l}\mathrm{PH}: \mathrm{C} \times 43^{+/-} \downarrow \text { pulmonary arterial } \\
\text { muscularization, inflammatory } \\
\text { infiltration }\end{array}$ & [70] \\
\hline Rat & PASMC transduced with miR-1 & Cx43 expression $\downarrow$ & [71] \\
\hline Rat & $\begin{array}{l}\text { Sugen } 5416(20 \mathrm{mg} / \mathrm{kg}) \text { followed by } 2 \mathrm{w} \\
\text { hypoxia and } 3 \mathrm{w} \text { normoxia; GS- } 444217 \\
(10 \mu \mathrm{M}) \text { during normoxia }\end{array}$ & $\begin{array}{l}\text { Sugen } 5416 / \text { hypoxia: Cx } 43 \text { protein } \uparrow \text { in } \\
\text { lung tissue, effect reversed by GS- } 444217\end{array}$ & [72] \\
\hline
\end{tabular}

IPAH: idiopathic pulmonary arterial hypertension; MCT: monocrotaline; PAEC: pulmonary arterial endothelial cells; PASMC: pulmonary arterial smooth muscle cells; PH: pulmonary hypertension; $\uparrow:$ increased; $\downarrow$ : decreased.

\subsection{Pulmonary Hypertension: Connexins in Right Ventricular Hypertrophy and Failure}

$\mathrm{PH}$ results from increased pulmonary vascular resistance. Chronic pressure overload stimulates RV hypertrophy, which can compensate for the increased RV afterload by reducing wall stress and energy demand. However, sustained pressure overload induces RV decompensation with dilatation and failure [73]. Since patients with RV decompensation have a higher risk of suffering from arrhythmias, it is worth studying electrophysiological remodeling in animal models of $\mathrm{PH}$. The administration of monocrotaline alters the electrophysical properties of the RV in several aspects. At rapid heart rates, ventricular tachyarrhythmias occur in monocrotaline-treated rats [74]. In addition, a prolongation of action potential duration and increased action potential duration heterogeneity are observed [74]. Whereas in the hypertrophied RV the repolarization is prolonged, the failing RV shows an increase in repolarization heterogeneity [75]. In addition, it is suggested that the atrioventricular node dysfunction observed after monocrotaline treatment is due to changes in the mRNA profiles of ion channels [76]. Monocrotaline not only alters the electrical properties of the RV but also those of the right atrium. Here, monocrotaline induces a substrate for the maintenance of atrial fibrillation due to right atrial re-entrant activity [77].

Since impulse propagation in the heart is mediated via connexin-formed gap junctional channels and the preservation of connexin topology has anti-arrhythmic effects [78-80], the alterations of right atrial and ventricular electrophysical properties suggest a deregulation of connexin expression/function in experimental models of PH. The amount of Cx43 is assessed at different time periods after administration of monocrotaline. Compared to control RV samples, decreased amounts of the Cx43 mRNA and protein are detected in RV tissue 4 weeks [81], 5 weeks [82,83] and 6-7 weeks [74] after monocrotaline treatment. The downregulation of $\mathrm{Cx} 43$ persists at least until 90 days after monocrotaline administration, when a reduced protein amount of the protein is detected $[84,85]$. The protein level of Cx43 90 days after injection of monocrotaline is not only reduced in the RV but also in the lung [86], whereas 5 weeks after injection, higher Cx43 protein amounts in the lung are observed [83]. The downregulation of $\mathrm{Cx} 43$ in monocrotaline-treated rats is not restricted to the RV; rather, the expression of $\mathrm{Cx} 43$ is also altered in other compartments of the heart. In the right 
atrium, the Cx43 mRNA is reduced 3 weeks after monocrotaline injection [77]. The analysis of the amount of Cx43 in LV tissue of monocrotaline-treated rats revealed non-consistent results: whereas one study demonstrates decreased $\mathrm{C} \times 43$ protein levels approximately 4 weeks after administration of monocrotaline [87], others show no alteration of the Cx43 protein 5 weeks after monocrotaline-injection [82]. Data on the phosphorylation of Cx43 in the monocrotaline model are rare. One study indicates decreased phosphorylation of Cx43 4 weeks after monocrotaline-treatment in RV tissue-without analysis of specific phosphorylation sites, whereas the total amount of the protein is not affected [88]. Others describe maintained Cx43 protein amount 4 weeks after monocrotaline administration [89]. Interestingly, despite the maintained $\mathrm{C} \times 43$ protein level in monocrotaline-treated rats, the aforementioned studies describe an increased lateralization of $\mathrm{Cx} 43$, which is confirmed 5 weeks after monocrotaline injection [90].

Although the monocrotaline model represents a severe model of $\mathrm{PH}$ with increased $\mathrm{RV}$ overload, direct effect of monocrotaline on the RV cannot be completely ruled out in the above studies. In addition to the monocrotaline model, connexin expression and function are also studied after PAB, where such direct effect of a PH-inducing drug on the RV is absent. In fetal sheep RV tissue, the mRNA of both Cx40 and Cx43 decreases after chronic overload (5 days) [91]. In addition to decreased amounts of $C \times 40$ and $C \times 43$, a decline in the level of the Cx37 mRNA is detected in mouse RV tissue 2 weeks after banding of the pulmonary artery [92]. In papillary muscles isolated 4-6 weeks after the PAB operation, the amount of the Cx43 mRNA and protein declines especially in tissue samples with interstitial fibrosis compared to those without fibrosis. Here, also a disorganization of the intercalated discs is observed [93], making it likely that diminished cell-cell communication contributes to the disturbance of myocyte synchronous activation. In addition, adult sheep subjected to RV pressure overload display enhanced Cx43 lateralization; however, concurrent lateralization of microtubule-associated proteins relevant for $\mathrm{Cx} 43$ trafficking suggests that lateralization may represent an adaptive mechanism that prevents uncoupling [94].

Whereas the majority of the studies show a downregulation of $\mathrm{C} \times 43$ after PAB, also enhanced amounts of the Cx43 mRNA are detected in RV tissue 7 weeks after the induction of compensated hypertrophy or RV failure by PAB [95]. Data on the electrophysiological properties of the RV in different models of $\mathrm{PH}$, as well as on the expression and localization of Cx43, are given in Table 4 .

Table 4. Pulmonary hypertension: connexins in RV hypertrophy and failure.

\begin{tabular}{|c|c|c|c|}
\hline Species & Model & Result & Reference \\
\hline Rat & $\begin{array}{l}\text { MCT }(60 \mathrm{mg} / \mathrm{kg}) \text { or saline, analysis after } \\
6-7 \mathrm{w}\end{array}$ & $\begin{array}{l}\text { PH: action potential duration } \uparrow \text {, action } \\
\text { potential duration heterogeneity } \uparrow, \mathrm{Cx} 43 \\
\text { mRNA and protein } \downarrow\end{array}$ & [74] \\
\hline Rat & $\begin{array}{l}\text { MCT }(60 \mathrm{mg} / \mathrm{kg}) \text { or control, analysis after } \\
5-8 \mathrm{w}\end{array}$ & $\begin{array}{l}\text { RVH: prolongation of ventricular } \\
\text { repolarization; } \\
\text { Failing RV: repolarization heterogeneity } \uparrow\end{array}$ & [75] \\
\hline Rat & MCT $(60 \mathrm{mg} / \mathrm{kg})$ or saline, analysis after $4 \mathrm{w}$ & $\begin{array}{l}\text { PH: atrioventricular node dysfunction } \\
\text { associated with derangement in the ion } \\
\text { channel transcriptome }\end{array}$ & [76] \\
\hline Rat & MCT $(60 \mathrm{mg} / \mathrm{kg})$ or saline, analysis after $3 \mathrm{w}$ & $\begin{array}{l}\text { PH: pacing-induced atrial fibrillation } \uparrow \text {, } \\
\text { conduction slowing and rotor activity, } \\
\text { transcriptome derangement related to } \\
\text { hypertrophy, inflammation, fibrosis in RA; } \\
\text { RA: Cx43 mRNA } \downarrow\end{array}$ & [77] \\
\hline Rat & $\begin{array}{l}\text { MCT }(60 \mathrm{mg} / \mathrm{kg}) \text { or no treatment, analysis } \\
\text { after } 4 \mathrm{w}\end{array}$ & PH: Cx43 protein $\downarrow$ & [81] \\
\hline Rat & MCT $(60 \mathrm{mg} / \mathrm{kg})$ or saline, analysis after $5 \mathrm{w}$ & $\begin{array}{l}\text { PH: RV: Cx43 mRNA and protein; LV: Cx43 } \\
\text { unchanged } \downarrow\end{array}$ & {$[82]$} \\
\hline Rat & MCT $(70 \mathrm{mg} / \mathrm{kg})$ or saline, analysis after $5 \mathrm{w}$ & PH: RV: Cx43 protein $\downarrow$; lung: Cx43 protein $\uparrow$ & [83] \\
\hline
\end{tabular}


Table 4. Cont.

\begin{tabular}{|c|c|c|c|}
\hline Species & Model & Result & Reference \\
\hline Rat & MCT $(60 \mathrm{mg} / \mathrm{kg})$ or saline, analysis after $90 \mathrm{~d}$ & PH: Cx43 protein $\downarrow$ & [84] \\
\hline Rat & MCT $(65 \mathrm{mg} / \mathrm{kg})$ or saline, analysis after $90 \mathrm{~d}$ & PH: RV: Cx43 protein $\downarrow$; lung: Cx43 protein $\uparrow$ & [85] \\
\hline Rat & MCT $(75 \mathrm{mg} / \mathrm{kg})$ or saline, analysis after $90 \mathrm{~d}$ & PH: RV: Cx43 protein $\downarrow$; lung: Cx43 protein $\downarrow$ & [86] \\
\hline Rat & $\begin{array}{l}\text { MCT }(60 \mathrm{mg} / \mathrm{kg}) \text { or saline, analysis after } \\
\text { approximately } 4 \mathrm{w}\end{array}$ & PH: RV and LV: Cx43 protein $\downarrow$ & [87] \\
\hline Rat & MCT $(60 \mathrm{mg} / \mathrm{kg})$ or saline, analysis after $4 \mathrm{w}$ & $\begin{array}{l}\text { PH: Cx43 protein lateralization } \uparrow ; C x 43 \\
\text { phosphorylation } \downarrow ; C x 43 \text { protein unchanged }\end{array}$ & [88] \\
\hline Rat & MCT $(60 \mathrm{mg} / \mathrm{kg})$ or saline, analysis after $4 \mathrm{w}$ & $\begin{array}{l}\text { PH: } \mathrm{C} \times 43 \text { protein lateralization } \uparrow \text {; } \mathrm{C} \times 43 \\
\text { protein unchanged }\end{array}$ & [89] \\
\hline Rat & MCT $(60 \mathrm{mg} / \mathrm{kg})$ or saline, analysis after $5 \mathrm{w}$ & $\begin{array}{l}\mathrm{PH}: \mathrm{C} \times 43 \text { protein lateralization } \uparrow ; \mathrm{C} \times 43 \\
\text { protein unchanged }\end{array}$ & {$[90]$} \\
\hline Sheep & $\begin{array}{l}\text { PAB in fetal sheep for } 1 \mathrm{~h} \text { or } 5 \mathrm{~d} \text {; control: } \\
\text { unbanded twin fetus }\end{array}$ & PAB: RV: $\mathrm{Cx} 40$ and $\mathrm{C} \times 43 \mathrm{mRNA} \downarrow 5 \mathrm{~d}$ & [91] \\
\hline Mouse & PAB or sham surgery, analysis after $2 \mathrm{w}$ & PAB: RV: Cx37 mRNA $\downarrow$ & [92] \\
\hline Rat & PAB or sham surgery, analysis after $4-6 \mathrm{w}$ & $\begin{array}{l}\text { Papillary muscles with fibrosis: Cx43 mRNA } \\
\text { and protein } \downarrow \text { compared to tissue without } \\
\text { fibrosis; disorganized intercalated discs }\end{array}$ & [93] \\
\hline Sheep & $\begin{array}{l}\text { Injection of sephadex beads, analysis after } \\
60 \mathrm{~d}\end{array}$ & $\begin{array}{l}\text { PH: lateralization of } \mathrm{C} \times 43 \text { and } \\
\text { microtubule-associated proteins } \uparrow\end{array}$ & [94] \\
\hline Rat & $\begin{array}{l}\text { Pulmonary trunk banding with a diameter of } \\
0.6 \mathrm{~mm} \text { or } 0.5 \mathrm{~mm} \text { to induce compensated or } \\
\text { decompensated } \mathrm{HF} \text {, analysis after } 7 \mathrm{w}\end{array}$ & $\begin{array}{l}\text { Compensated and decompensated HF: } \\
\text { Cx43 mRNA } \uparrow\end{array}$ & [95] \\
\hline
\end{tabular}

HF: heart failure; MCT: monocrotaline; PH: pulmonary hypertension; RA; right atrium; RVH: right ventricular hypertrophy; SERCA2a: sarcoplasmic reticulum calcium ATPase 2a; $\uparrow:$ increased; $\downarrow$ : decreased.

\section{Connexins and Treatment of Pulmonary Hypertension}

The findings that, in pulmonary hypertension, the expression of connexins, especially $\mathrm{C} \times 43$, is reduced and a lateralization of the protein occurs suggest that strategies to treat $\mathrm{PH}$ may also affect the amounts of connexins as well as their function. Therefore, different approaches to improve RV function in $\mathrm{PH}$ consider the role of connexins and the respective studies are discussed in the following section.

The activation of the vasoconstrictive-proliferative axis of the renin angiotensin system leads to the development of $\mathrm{PH}$, whereas the activation of the counterbalancing axis via the conversion of Angiotensin II to Ang-(1-7) by the angiotensin-converting enzyme 2(ACE2) protects against $\mathrm{PH}$ in monocrotaline-treated rats [96] and is a promising strategy in humans [97]. In mice, the infusion of recombinant ACE2 decreases RV hypertrophy and increases RV ejection fraction after PAB. Whereas the expression of $\mathrm{Cx} 37$ is downregulated after $\mathrm{PAB}$, the improved RV function after ACE2 infusion is associated with a normalized expression of Cx37 [92]. Possibly, Cx37-mediated cell-cell communication contributes to the protective effects of the ACE2 infusion.

The expression of Cx37 and Cx40 is regulated by the cis-acting factor MEF2 (myocyte enhancer factor 2), the activity of which is reduced in PH. The pharmacological inhibition of class IIa histone deacetylases using MC1568 restores MEF2 activity and increases the levels of the Cx37 and Cx40 mRNAs and, moreover, decreases the proliferation of pulmonary artery endothelial cells isolated from patients with $\mathrm{PH}$ and reduces RV systolic pressure and RV hypertrophy in monocrotaline-treated rats [67].

The enhanced proliferation of the pulmonary arterial vascular smooth muscle cells in $\mathrm{PH}$ is associated with alterations in the calcium homeostasis. In monocrotaline-treated rats, the expression of the sarcoplasmic calcium ATPase 2a (SERCA2a) is downregulated [74], an effect contributing to electrophysiological remodeling. Accordingly, it is hypothesized 
that a normalization of the SERCA2a expression will improve vascular remodeling and will reduce pacing-induced ventricular tachyarrhythmia in PH. Indeed, intra-tracheal gene delivery of aerosolized SERCA2a to the lung normalizes the expression level of SERCA2a and of subunits of potassium channels in the RV and accordingly decreases the occurrence of pacing-induced ventricular tachyarrhythmia. In addition, the amounts of the Cx43 mRNA and protein, which are reduced after the administration of monocrotaline, are increased after SERCA2a delivery and nearly reach the levels detected in the control group [74].

A study by Lee et al. [84] focusses on the role of potassium channels in PH. Here, the administration of nicorandil, which has vasodilatory properties due to regulating the opening of ATP-dependent potassium channels and the release of nitric oxide, to monocrotaline-treated rats decreases the RV systolic blood pressure, the weight of the $\mathrm{RV}$ and inhibits the proliferation of smooth muscle cells. Compared to the injection of monocrotaline alone, the administration of nicorandil enhances the protein amount of Cx43. A further elevation of the Cx43 expression is observed following the combined administration of nicorandil and colchicine, which prevents microtubule polymerization.

Another therapeutic approach to ameliorate $\mathrm{PH}$ in monocrotaline-treated rats is the administration of cilostazol, which exerts antiproliferative effects on vascular endothelial and smooth muscle cells [86]. The use of cilostazol reduces RV systolic blood pressure and $\mathrm{RV}$ hypertrophy. This protective effect is associated with the enhanced expression of $\mathrm{C} \times 43$ in the RV and in the lung and it is suggested that the preserved protein level of $\mathrm{Cx} 43$ in cilostazol-treated animals contributes to the reduced RV wall stress and hypertrophy.

In addition, sildenafil treatment prevents the downregulation of Cx43 in the RV of monocrotaline-treated rats [85].

The endothelin receptor antagonist bosentan, which is capable of improving PH [98] and hemodynamics in $\mathrm{PH}$ patients [99], also reduces $\mathrm{RV}$ systolic blood pressure, but not the $\mathrm{RV} / \mathrm{LV}$ thickness ratio in monocrotaline-treated rats [90]. In contrast to the aforementioned studies, the investigation by Tan et al. [90] focuses on the distribution of the Cx43 at the $\mathrm{RV}$ cardiomyocyte plasma membrane. Here, a lateralization of $\mathrm{Cx} 43$ is observed after the administration of monocrotaline. Such alteration of the $\mathrm{C} \times 43$ distribution is not visible after bosentan treatment.

The aforementioned studies all demonstrate that protection against $\mathrm{PH}$ is associated with preservation of connexin expression and/or localization. In contrast, monocrotalinetreated rats have an increased number of $\mathrm{Cx} 40$ - and $\mathrm{Cx} 43$-expressing $\mathrm{CD} 4^{+}$and $\mathrm{CD} 8^{+}$ $\mathrm{T}$ cells in lung tissue and the administration of the unspecific gap junction blocker carbenoxolone decreases the expression of these connexins and reduces RV hypertrophy in monocrotaline-treated rats [100]. These data show that the inhibition of connexins decrease the monocrotaline-induced pulmonary inflammatory response.

In Table 5, therapeutic approaches to improve RV function in $\mathrm{PH}$, which are associated with alterations of connexin expression and/or function are presented.

Table 5. Therapeutic approaches to improve RV function in PH involving connexins.

\begin{tabular}{|c|c|c|c|}
\hline Species & Model & Result & Reference \\
\hline Mouse & $\begin{array}{l}\text { PAB or sham surgery, rhACE2 } \\
(1.8 \mathrm{mg} / \mathrm{kg} / \mathrm{d}) \text { or vehicle on post-op } \\
\text { day } 2, \text { analysis } 2 \mathrm{w} \text { after surgery }\end{array}$ & $\begin{array}{l}\text { rhACE2: EF } \uparrow, \text { RVH } \downarrow \text {; normalized the } \\
\text { decreased Cx37 mRNA after PAB }\end{array}$ & [92] \\
\hline Human & $\begin{array}{l}\text { PAECs from PH patients treated with } \\
1 \mu \mathrm{M} \text { MC1568 for } 24 \mathrm{~h}\end{array}$ & $\begin{array}{l}\text { MC1568: normalized the decreased Cx37 } \\
\text { and Cx40 expression }\end{array}$ & \multirow{2}{*}{ [67] } \\
\hline Rat & $\begin{array}{l}\text { MCT }(60 \mathrm{mg} / \mathrm{kg}) \text { or saline, MC1568 } \\
(50 \mathrm{mg} / \mathrm{kg}) \text { or saline daily }\end{array}$ & MC1568: RVSP $\downarrow$, RVH $\downarrow$ & \\
\hline Rat & $\begin{array}{l}\text { MCT }(60 \mathrm{mg} / \mathrm{kg}) \text { or saline, after } 3 \mathrm{w} \text { : } \\
\text { intra-tracheal delivery of aerosolized } \\
\text { AAV1.SERCA2a or no treatment, analysis } \\
\text { after additional } 3-4 \mathrm{w}\end{array}$ & $\begin{array}{l}\text { AAV1.SERCA2a: reversal of } \\
\text { electrophysiological remodeling; RV: } \\
\text { normalized amounts of Cx } 43 \text { mRNA and } \\
\text { protein; normalized amounts of } \\
\text { SERCA2a, of ion channels }\end{array}$ & [74] \\
\hline
\end{tabular}


Table 5. Cont.

\begin{tabular}{|c|c|c|c|}
\hline Species & Model & Result & Reference \\
\hline Rat & $\begin{array}{l}\text { MCT }(60 \mathrm{mg} / \mathrm{kg}), \mathrm{MCT}+\text { nicorandil } \\
(5 \mathrm{mg} / \mathrm{kg} / \mathrm{d}), \mathrm{MCT}+\text { colchicine } \\
(1 \mathrm{mg} / \mathrm{kg} / \mathrm{d}), \mathrm{MCT}+\text { nicorandil + } \\
\text { colchicine, analysis after } 90 \mathrm{~d}\end{array}$ & $\begin{array}{l}\text { Compared to MCT alone: all groups } \\
\text { showed RVSP } \downarrow, R V H \downarrow \text {, normalization of } \\
\text { Cx43 protein }\end{array}$ & [84] \\
\hline Rat & $\begin{array}{l}\text { MCT }(75 \mathrm{mg} / \mathrm{kg}), \mathrm{MCT}+\text { cilostazol } \\
(20 \mathrm{mg} / \mathrm{kg} / \mathrm{d}, \text { day } 28-90) \text { or saline, } \\
\text { analysis after } 90 \mathrm{~d}\end{array}$ & $\begin{array}{l}\text { Cilostazol: RVSP } \downarrow, \mathrm{RVH} \downarrow, \mathrm{Cx} 43 \text { protein } \\
\text { in RV and lung } \uparrow\end{array}$ & [86] \\
\hline Rat & $\begin{array}{l}\text { MCT }(65 \mathrm{mg} / \mathrm{kg}), \mathrm{MCT}+\text { sildenafil } \\
(25 \mathrm{mg} / \mathrm{kg} / \mathrm{d} \text {, } \\
\text { Day } 21-90) \text { or saline, analysis after } 90 \mathrm{~d}\end{array}$ & $\begin{array}{l}\text { Sildenafil: RVSP } \downarrow \text {, RV weight } \downarrow, \mathrm{Cx} 43 \\
\text { protein in } \mathrm{RV} \uparrow\end{array}$ & [85] \\
\hline Rat & $\begin{array}{l}\text { MCT }(60 \mathrm{mg} / \mathrm{kg}), \mathrm{MCT}+\text { bosentan } \\
(300 \mathrm{mg} / \mathrm{kg} / \mathrm{d} \text {, starting } 2 \mathrm{w} \text { after MCT, } \\
\text { or vehicle, analysis } 5 \mathrm{w} \text { after MCT }\end{array}$ & $\begin{array}{l}\text { Bosentan: RVSP } \downarrow, \text { RV /LV thickness ratio } \\
\text { unchanged, prevention of Cx43 } \\
\text { lateralization }\end{array}$ & [90] \\
\hline Rat & $\begin{array}{l}\text { MCT }(60 \mathrm{mg} / \mathrm{kg}), \mathrm{MCT}+\text { Carbenoxolone } \\
(20 \mathrm{mg} / \mathrm{kg} / \mathrm{d}) \text {, analysis after } 4 \mathrm{w}\end{array}$ & $\begin{array}{l}\text { Carbenoxolone: } \mathrm{RVH} \downarrow ; \mathrm{Cx} 43 \text {-expressing } \\
\mathrm{CD}^{+} \text {and } \mathrm{CD} 8^{+} \text {cells in lungs of } \\
\text { MCT-treated rats }\end{array}$ & [100] \\
\hline
\end{tabular}

EF: ejection fraction; HF: heart failure; MCT: monocrotaline; LV: left ventricle; PAEC: pulmonary arterial endothelial cells; PH: pulmonary hypertension; rhACE2: recombinant human angiotensin-converting enzyme 2; RVH: right ventricular hypertrophy; RVSP: right ventricular systolic pressure; SERCA2a: sarcoplasmic reticulum calcium ATPase 2a; $\uparrow:$ increased; $\downarrow$ : decreased.

Taken together, whereas the amounts of connexin proteins are reduced and the distribution of $\mathrm{Cx} 43$ at the plasma membrane is disturbed in $\mathrm{PH}$, different therapeutic approaches to improve $\mathrm{RV}$ function in $\mathrm{PH}$ are associated with a normalization of connexin expression and its localization at the plasma membrane. However, a causal role of connexins in the reduction in RV systolic blood pressure and RV hypertrophy is yet unproven.

\section{Conclusions}

A contribution of connexins, especially Cx43, towards the development of LV hypertrophy and failure is demonstrated in several studies; however, the role of connexins in the diseased RV is less studied. In general, the protein amount of Cx43 is similar in RV and LV tissue, both at the level of the total protein extracts and within mitochondria. In the RV, connexins seem to play a role in the tetralogy of Fallot and in PH. Here, alterations in the expression of connexins are detected in vascular cells as well as in RV tissue. Frequently, $\mathrm{Cx} 43$ is downregulated in $\mathrm{PH}$ and an increased lateralization of the protein is observed. Whether or not mitochondrial Cx43 contributes to the development of $\mathrm{PH}$ is yet unclear. Therapeutic approaches that improve RV function in PH are often associated with a normalization of the Cx43 expression (see Figure 2). Whereas data on the signal transduction and mechanisms leading to $\mathrm{Cx} 43$ dysregulation are limited and no causality between dysfunctional Cx43 and the development of RV hypertrophy and failure is proven yet, the available data legitimate the need for further studies on the role of Cx43 in the diseased RV. 
vasculature

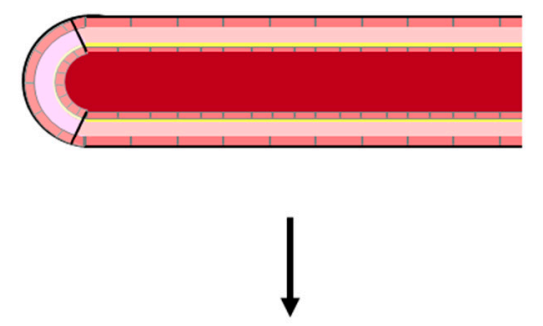

Induction of $\mathrm{PH}$

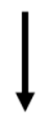

RV

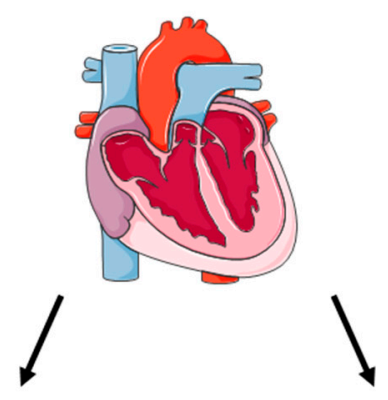

Induction of $\mathrm{PH}$

therapeutic approach

to treat $\mathrm{PH}$ $\downarrow$

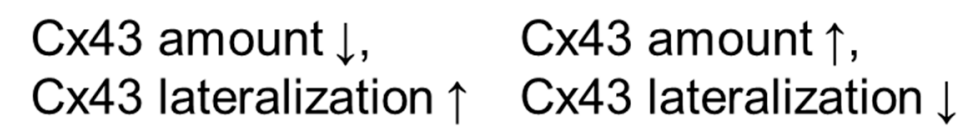

Figure 2. Schematic representation of the expression and localization of $\mathrm{Cx} 43$ in pulmonary hypertension (PH). In the vasculature, the amount of $\mathrm{Cx} 43$ depends on the exact form of $\mathrm{PH}$. In the right ventricle (RV), $\mathrm{PH}$ is associated with a downregulation of $\mathrm{Cx} 43$ as well as with enhanced lateralization of the protein. Therapeutic approaches to treat $\mathrm{PH}$ can maintain Cx43 expression and localization. Schematic representation of the heart: copyright (C) 2005, Les Laboratoires Servier. PAH: pulmonary arterial hypertension.

Supplementary Materials: The following are available online at https: / www.mdpi.com/1422-0 067/22/3/987/s1, Figure S1: Purity of SSM and IFM isolated from mouse right and left ventricles. Figure S2: Expression of Cx43 in right and left ventricular tissue: unedited Western Blot images.

Author Contributions: K.B. drafted the manuscript, S.R., N.W. and R.S. substantively revised the manuscript. All authors have read and agreed to the published version of the manuscript.

Funding: This work was supported by the "Deutsche Forschungsgemeinschaft" (DFG, German Research Foundation), project number 268555672-SFB 1213, projects A06, B05, and Bo 2955-4/1.

Institutional Review Board Statement: The study was approved by the animal welfare office of the Justus-Liebig University, Giessen, Germany (522_M, approved 29 November 2019).

Informed Consent Statement: Not applicable.

Data Availability Statement: Full, uncut Western blot analysis is presented in Supplementary Materials Figure S2.

Acknowledgments: We thank Sabrina Boehme for excellent technical assistance.

Conflicts of Interest: The authors declare no conflict of interest.

\section{References}

1. Goodenough, D.A.; Paul, D.L. Beyond the gap: Functions of unpaired connexon channels. Nat. Rev. Mol. Cell Biol. 2003, 4, 285-294. [CrossRef] [PubMed]

2. Leybaert, L.; Lampe, P.D.; Dhein, S.; Kwak, B.R.; Ferdinandy, P.; Beyer, E.C.; Laird, D.W.; Naus, C.C.; Green, C.R.; Schulz, R. Connexins in Cardiovascular and Neurovascular Health and Disease: Pharmacological Implications. Pharmacol. Rev. 2017, 69, 396-478. [CrossRef] [PubMed]

3. Vielma, A.Z.; Boric, M.P.; Gonzalez, D.R. Apocynin Treatment Prevents Cardiac Connexin 43 Hemichannels Hyperactivity by Reducing Nitroso-Redox Stress in Mdx Mice. Int. J. Mol. Sci. 2020, 21, 5415. [CrossRef] [PubMed] 
4. Lissoni, A.; Hulpiau, P.; Martins-Marques, T.; Wang, N.; Bultynck, G.; Schulz, R.; Witschas, K.; Girao, H.; De Smet, M.; Leybaert, L. RyR2 regulates Cx43 hemichannel intracellular $\mathrm{Ca}^{2+}$-dependent activation in cardiomyocytes. Cardiovasc. Res. 2019. [CrossRef] [PubMed]

5. Martins-Marques, T.; Pinho, M.J.; Zuzarte, M.; Oliveira, C.; Pereira, P.; Sluijter, J.P.; Gomes, C.; Girao, H. Presence of Cx43 in extracellular vesicles reduces the cardiotoxicity of the anti-tumour therapeutic approach with doxorubicin. J. Extracell. Vesicles 2016, 5, 32538. [CrossRef]

6. $\quad$ Martins-Marques, T.; Ribeiro-Rodrigues, T.; de Jager, S.C.; Zuzarte, M.; Ferreira, C.; Cruz, P.; Reis, L.; Baptista, R.; Gonçalves, L.; Sluijter, J.P.; et al. Myocardial infarction affects Cx43 content of extracellular vesicles secreted by cardiomyocytes. Life Sci. Alliance 2020, 3, e202000821. [CrossRef]

7. Boengler, K.; Dodoni, G.; Rodriguez-Sinovas, A.; Cabestrero, A.; Ruiz-Meana, M.; Gres, P.; Konietzka, I.; Lopez-Iglesias, C.; Garcia-Dorado, D.; Di Lisa, F.; et al. Connexin 43 in cardiomyocyte mitochondria and its increase by ischemic preconditioning. Cardiovasc. Res. 2005, 67, 234-244. [CrossRef]

8. Boengler, K.; Stahlhofen, S.; van de Sand, A.; Gres, P.; Ruiz-Meana, M.; Garcia-Dorado, D.; Heusch, G.; Schulz, R. Presence of connexin 43 in subsarcolemmal, but not in interfibrillar cardiomyocyte mitochondria. Basic Res. Cardiol. 2009, 104, 141-147. [CrossRef]

9. Rodriguez-Sinovas, A.; Boengler, K.; Cabestrero, A.; Gres, P.; Morente, M.; Ruiz-Meana, M.; Konietzka, I.; Miro, E.; Totzeck, A.; Heusch, G.; et al. Translocation of connexin 43 to the inner mitochondrial membrane of cardiomyocytes through the heat shock protein 90-dependent TOM pathway and its importance for cardioprotection. Circ. Res. 2006, 99, 93-101. [CrossRef]

10. Palmer, J.W.; Tandler, B.; Hoppel, C.L. Biochemical properties of subsarcolemmal and interfibrillar mitochondria isolated from rat cardiac muscle. J. Biol. Chem. 1977, 252, 8731-8739. [CrossRef]

11. Palmer, J.W.; Tandler, B.; Hoppel, C.L. Heterogeneous response of subsarcolemmal heart mitochondria to calcium. Am. J. Physiol. 1986, 250, H741-H748. [CrossRef] [PubMed]

12. Boengler, K.; Ruiz-Meana, M.; Gent, S.; Ungefug, E.; Soetkamp, D.; Miro-Casas, E.; Cabestrero, A.; Fernandez-Sanz, C.; Semenzato, M.; Di Lisa, F.; et al. Mitochondrial connexin 43 impacts on respiratory complex I activity and mitochondrial oxygen consumption. J. Cell. Mol. Med. 2012, 16, 1649-1655. [CrossRef] [PubMed]

13. Soetkamp, D.; Nguyen, T.T.; Menazza, S.; Hirschhauser, C.; Hendgen-Cotta, U.B.; Rassaf, T.; Schluter, K.D.; Boengler, K.; Murphy, E.; Schulz, R. S-nitrosation of mitochondrial connexin 43 regulates mitochondrial function. Basic Res. Cardiol. 2014, 109, 433. [CrossRef] [PubMed]

14. Tu, R.H.; Li, Q.J.; Huang, Z.; He, Y.; Meng, J.J.; Zheng, H.L.; Zeng, Z.Y.; Zhong, G.Q. Novel Functional Role of Heat Shock Protein 90 in Mitochondrial Connexin 43-Mediated Hypoxic Postconditioning. Cell. Physiol. Biochem. 2017, 44, 982-997. [CrossRef] [PubMed]

15. Srisakuldee, W.; Makazan, Z.; Nickel, B.E.; Zhang, F.; Thliveris, J.A.; Pasumarthi, K.B.; Kardami, E. The FGF-2-triggered protection of cardiac subsarcolemmal mitochondria from calcium overload is mitochondrial connexin 43-dependent. Cardiovasc. Res. 2014, 103, 72-80. [CrossRef] [PubMed]

16. Boengler, K.; Ungefug, E.; Heusch, G.; Leybaert, L.; Schulz, R. Connexin 43 impacts on mitochondrial potassium uptake. Front. Pharmacol. 2013, 4, 73. [CrossRef]

17. Smyth, J.W.; Shaw, R.M. Autoregulation of connexin43 gap junction formation by internally translated isoforms. Cell Rep. 2013, 5, 611-618. [CrossRef]

18. Xiao, S.; Shimura, D.; Baum, R.; Hernandez, D.M.; Agvanian, S.; Nagaoka, Y.; Katsumata, M.; Lampe, P.D.; Kleber, A.G.; Hong, T.; et al. Auxiliary trafficking subunit GJA1-20k protects connexin-43 from degradation and limits ventricular arrhythmias. J. Clin. Investig. 2020, 130, 4858-4870. [CrossRef]

19. Wang, M.; Smith, K.; Yu, Q.; Miller, C.; Singh, K.; Sen, C.K. Mitochondrial connexin 43 in sex-dependent myocardial responses and estrogen-mediated cardiac protection following acute ischemia/reperfusion injury. Basic Res. Cardiol. 2019, 115, 1. [CrossRef]

20. Fu, Y.L.; Tao, L.; Peng, F.H.; Zheng, N.Z.; Lin, Q.; Cai, S.Y.; Wang, Q. GJA1-20k attenuates Ang II-induced pathological cardiac hypertrophy by regulating gap junction formation and mitochondrial function. Acta Pharmacol. Sin. 2020, 1-14. [CrossRef]

21. Epifantseva, I.; Xiao, S.; Baum, R.E.; Kléber, A.G.; Hong, T.; Shaw, R.M. An Alternatively Translated Connexin 43 Isoform, GJA1-11k, Localizes to the Nucleus and Can Inhibit Cell Cycle Progression. Biomolecules 2020, 10, 473. [CrossRef] [PubMed]

22. Solan, J.L.; Lampe, P.D. Spatio-temporal regulation of connexin 43 phosphorylation and gap junction dynamics. Biochim. Biophys. Acta 2018, 1860, 83-90. [CrossRef]

23. Chen, W.; Guo, Y.; Yang, W.; Chen, L.; Ren, D.; Wu, C.; He, B.; Zheng, P.; Tong, W. Phosphorylation of connexin 43 induced by traumatic brain injury promotes exosome release. J. Neurophysiol. 2018, 119, 305-311. [CrossRef] [PubMed]

24. Boengler, K.; Schulz, R. Connexin 43 and Mitochondria in Cardiovascular Health and Disease. Adv. Exp. Med. Biol. 2017, 982, 227-246. [PubMed]

25. Totland, M.Z.; Rasmussen, N.L.; Knudsen, L.M.; Leithe, E. Regulation of gap junction intercellular communication by connexin ubiquitination: Physiological and pathophysiological implications. Cell. Mol. Life Sci. 2020, 77, 573-591. [CrossRef] [PubMed]

26. Martins-Marques, T.; Catarino, S.; Gonçalves, A.; Miranda-Silva, D.; Gonçalves, L.; Antunes, P.; Coutinho, G.; Leite Moreira, A.; Falcão Pires, I.; Girão, H. EHD1 Modulates Cx43 Gap Junction Remodeling Associated With Cardiac Diseases. Circ. Res. 2020, 126, e97-e113. [CrossRef] [PubMed]

27. Delorme, B.; Dahl, E.; Jarry-Guichard, T.; Briand, J.P.; Willecke, K.; Gros, D.; Théveniau-Ruissy, M. Expression pattern of connexin gene products at the early developmental stages of the mouse cardiovascular system. Circ. Res. 1997, 81, 423-437. [CrossRef] 
28. Louault, C.; Benamer, N.; Faivre, J.F.; Potreau, D.; Bescond, J. Implication of connexins 40 and 43 in functional coupling between mouse cardiac fibroblasts in primary culture. Biochim. Biophys. Acta 2008, 1778, 2097-2104. [CrossRef]

29. Vozzi, C.; Dupont, E.; Coppen, S.R.; Yeh, H.I.; Severs, N.J. Chamber-related differences in connexin expression in the human heart. Biochim. Biophys. Acta 1999, 31, 991-1003. [CrossRef]

30. Zhang, X.; Wang, X.; Zhou, X.; Ma, X.; Yao, Y.; Liu, X. Phenotypic transformation of smooth muscle cells from porcine coronary arteries is associated with connexin 43. Mol. Med. Rep. 2016, 14, 41-48. [CrossRef]

31. Greener, I.D.; Monfredi, O.; Inada, S.; Chandler, N.J.; Tellez, J.O.; Atkinson, A.; Taube, M.A.; Billeter, R.; Anderson, R.H.; Efimov, I.R.; et al. Molecular architecture of the human specialised atrioventricular conduction axis. J. Mol. Cell. Cardiol. 2011, 50, 642-651. [CrossRef] [PubMed]

32. Van Rijen, H.V.; van Veen, T.A.; van Kempen, M.J.; Wilms-Schopman, F.J.; Potse, M.; Krueger, O.; Willecke, K.; Opthof, T.; Jongsma, H.J.; de Bakker, J.M. Impaired conduction in the bundle branches of mouse hearts lacking the gap junction protein connexin40. Circulation 2001, 103, 1591-1598. [CrossRef] [PubMed]

33. Coppen, S.R.; Kaba, R.A.; Halliday, D.; Dupont, E.; Skepper, J.N.; Elneil, S.; Severs, N.J. Comparison of connexin expression patterns in the developing mouse heart and human foetal heart. Mol. Cell. Biochem. 2003, 242, 121-127. [CrossRef] [PubMed]

34. Noorman, M.; van Rijen, H.V.; van Veen, T.A.; de Bakker, J.M.; Stein, M. Differences in distribution of fibrosis in the ventricles underlie dominant arrhythmia vulnerability of the right ventricle in senescent mice. Neth. Heart J. 2008, 16, 356-358. [CrossRef] [PubMed]

35. Boukens, B.J.; Sylva, M.; de Gier-de Vries, C.; Remme, C.A.; Bezzina, C.R.; Christoffels, V.M.; Coronel, R. Reduced sodium channel function unmasks residual embryonic slow conduction in the adult right ventricular outflow tract. Circ. Res. 2013, 113, 137-141. [CrossRef] [PubMed]

36. Szeiffová Bačová, B.; Egan Beňová, T.; Viczenczová, C.; Soukup, T.; Rauchová, H.; Pavelka, S.; Knezl, V.; Barančík, M.; Tribulová, N. Cardiac connexin-43 and PKC signaling in rats with altered thyroid status without and with omega-3 fatty acids intake. Physiol. Res. 2016, 65 (Suppl. 1), S77-S90.

37. Nogueira-Ferreira, R.; Ferreira, R.; Padrão, A.I.; Oliveira, P.; Santos, M.; Kavazis, A.N.; Vitorino, R.; Moreira-Gonçalves, D. One year of exercise training promotes distinct adaptations in right and left ventricle of female Sprague-Dawley rats. J. Physiol. Biochem. 2019, 75, 561-572. [CrossRef]

38. Boengler, K.; Bulic, M.; Schreckenberg, R.; Schlueter, K.D.; Schulz, R. The gap junction modifier ZP1609 decreases cardiomyocyte hypercontracture following ischemia/reperfusion independent from mitochondrial connexin 43 . Br. $J$. Pharmacol. 2017, 174, 2606-2607. [CrossRef]

39. Sun, J.; Nguyen, T.; Aponte, A.M.; Menazza, S.; Kohr, M.J.; Roth, D.M.; Patel, H.H.; Murphy, E.; Steenbergen, C. Ischaemic preconditioning preferentially increases protein S-nitrosylation in subsarcolemmal mitochondria. Cardiovasc. Res. 2015, 106, 227-236. [CrossRef]

40. Severs, N.J.; Dupont, E.; Coppen, S.R.; Halliday, D.; Inett, E.; Baylis, D.; Rothery, S. Remodelling of gap junctions and connexin expression in heart disease. Biochim. Biophys. Acta 2004, 1662, 138-148. [CrossRef]

41. Reaume, A.G.; de Sousa, P.A.; Kulkarni, S.; Langille, B.L.; Zhu, D.; Davies, T.C.; Juneja, S.C.; Kidder, G.M.; Rossant, J. Cardiac malformation in neonatal mice lacking connexin43. Science 1995, 267, 1831-1834. [CrossRef] [PubMed]

42. Ya, J.; Erdtsieck-Ernste, E.B.; de Boer, P.A.; van Kempen, M.J.; Jongsma, H.; Gros, D.; Moorman, A.F.; Lamers, W.H. Heart defects in connexin43-deficient mice. Circ. Res. 1998, 82, 360-366. [CrossRef] [PubMed]

43. Huang, G.Y.; Wessels, A.; Smith, B.R.; Linask, K.K.; Ewart, J.L.; Lo, C.W. Alteration in connexin 43 gap junction gene dosage impairs conotruncal heart development. Dev. Biol. 1998, 198, 32-44. [CrossRef]

44. Sullivan, R.; Huang, G.Y.; Meyer, R.A.; Wessels, A.; Linask, K.K.; Lo, C.W. Heart malformations in transgenic mice exhibiting dominant negative inhibition of gap junctional communication in neural crest cells. Dev. Biol. 1998, 204, $224-234$. [CrossRef] [PubMed]

45. Wadghiri, Y.Z.; Schneider, A.E.; Gray, E.N.; Aristizabal, O.; Berrios, C.; Turnbull, D.H.; Gutstein, D.E. Contrast-enhanced MRI of right ventricular abnormalities in Cx43 mutant mouse embryos. NMR Biomed. 2007, 20, 366-374. [CrossRef]

46. Ou, B.; Nakagawa, M.; Kajimoto, M.; Nobe, S.; Ooie, T.; Ichinose, M.; Yonemochi, H.; Ono, N.; Shimada, T.; Saikawa, T. Heterogeneous expression of connexin 43 in the myocardium of rabbit right ventricular outflow tract. Life Sci. 2005, 77, 52-59. [CrossRef]

47. Li, W.E.; Waldo, K.; Linask, K.L.; Chen, T.; Wessels, A.; Parmacek, M.S.; Kirby, M.L.; Lo, C.W. An essential role for connexin43 gap junctions in mouse coronary artery development. Development 2002, 129, 2031-2042.

48. Ewart, J.L.; Cohen, M.F.; Meyer, R.A.; Huang, G.Y.; Wessels, A.; Gourdie, R.G.; Chin, A.J.; Park, S.M.; Lazatin, B.O.; Villabon, S.; et al. Heart and neural tube defects in transgenic mice overexpressing the Cx43 gap junction gene. Development 1997, $124,1281-1292$.

49. Liu, S.; Liu, F.; Schneider, A.E.; St Amand, T.; Epstein, J.A.; Gutstein, D.E. Distinct cardiac malformations caused by absence of connexin 43 in the neural crest and in the non-crest neural tube. Development 2006, 133, 2063-2073. [CrossRef]

50. Gu, H.; Smith, F.C.; Taffet, S.M.; Delmar, M. High incidence of cardiac malformations in connexin40-deficient mice. Circ. Res. 2003, 93, 201-206. [CrossRef]

51. Kirchhoff, S.; Kim, J.S.; Hagendorff, A.; Thönnissen, E.; Krüger, O.; Lamers, W.H.; Willecke, K. Abnormal cardiac conduction and morphogenesis in connexin 40 and connexin43 double-deficient mice. Circ. Res. 2000, 87, 399-405. [CrossRef] [PubMed] 
52. Gros, D.; Dupays, L.; Alcoléa, S.; Meysen, S.; Miquerol, L.; Théveniau-Ruissy, M. Genetically modified mice: Tools to decode the functions of connexins in the heart-new models for cardiovascular research. Cardiovasc. Res. 2004, 62, 299-308. [CrossRef] [PubMed]

53. Plum, A.; Hallas, G.; Magin, T.; Dombrowski, F.; Hagendorff, A.; Schumacher, B.; Wolpert, C.; Kim, J.; Lamers, W.H.; Evert, M.; et al. Unique and shared functions of different connexins in mice. Curr. Biol. 2000, 10, 1083-1091. [CrossRef]

54. Wu, Y.; Ma, X.J.; Wang, H.J.; Li, W.C.; Chen, L.; Ma, D.; Huang, G.Y. Expression of Cx43-related microRNAs in patients with tetralogy of Fallot. World J. Pediatr. 2014, 10, 138-144. [CrossRef] [PubMed]

55. Kołcz, J.; Drukała, J.; Bzowska, M.; Rajwa, B.; Korohoda, W.; Malec, E. The expression of connexin 43 in children with Tetralogy of Fallot. Cell. Mol. Biol. Lett. 2005, 10, 287-303. [PubMed]

56. Salameh, A.; Haunschild, J.; Brauchle, P.; Peim, O.; Seidel, T.; Reitmann, M.; Kostelka, M.; Bakhtiary, F.; Dhein, S.; Dahnert, I. On the role of the gap junction protein Cx43 (GJA1) in human cardiac malformations with Fallot-pathology. A study on paediatric cardiac specimen. PLoS ONE 2014, 9, e95344. [CrossRef] [PubMed]

57. Gu, R.; Xu, J.; Lin, Y.; Sheng, W.; Ma, D.; Ma, X.; Huang, G. The role of histone modification and a regulatory single-nucleotide polymorphism (rs2071166) in the Cx43 promoter in patients with TOF. Sci. Rep. 2017, 7, 10435. [CrossRef] [PubMed]

58. Huang, G.Y.; Xie, L.J.; Linask, K.L.; Zhang, C.; Zhao, X.Q.; Yang, Y.; Zhou, G.M.; Wu, Y.J.; Marquez-Rosado, L.; McElhinney, D.B.; et al. Evaluating the role of connexin43 in congenital heart disease: Screening for mutations in patients with outflow tract anomalies and the analysis of knock-in mouse models. J. Cardiovasc. Dis. Res. 2011, 2, 206-212. [CrossRef]

59. Guida, V.; Ferese, R.; Rocchetti, M.; Bonetti, M.; Sarkozy, A.; Cecchetti, S.; Gelmetti, V.; Lepri, F.; Copetti, M.; Lamorte, G.; et al. A variant in the carboxyl-terminus of connexin 40 alters GAP junctions and increases risk for tetralogy of Fallot. Eur. J. Hum. Genet. 2013, 21, 69-75. [CrossRef]

60. Benoist, D.; Dubes, V.; Roubertie, F.; Gilbert, S.H.; Charron, S.; Constantin, M.; Elbes, D.; Vieillot, D.; Quesson, B.; Cochet, H.; et al. Proarrhythmic remodelling of the right ventricle in a porcine model of repaired tetralogy of Fallot. Heart 2017, 103, 347-354. [CrossRef]

61. Dubes, V.; Benoist, D.; Roubertie, F.; Gilbert, S.H.; Constantin, M.; Charron, S.; Elbes, D.; Vieillot, D.; Quesson, B.; Cochet, H.; et al. Arrhythmogenic Remodeling of the Left Ventricle in a Porcine Model of Repaired Tetralogy of Fallot. Circulation 2018, 11, e006059. [CrossRef] [PubMed]

62. Chiu, S.N.; Tsai, C.T.; Lin, L.Y.; Huang, S.C.; Chen, Y.S.; Wang, J.K.; Wu, M.H.; Lai, L.P.; Lin, J.L. Repolarization Alternans and Ventricular Arrhythmia in a Repaired Tetralogy of Fallot Animal Model. J. Am. Heart Assoc. 2015, 4, e002173. [CrossRef] [PubMed]

63. Bueno-Beti, C.; Sassi, Y.; Hajjar, R.J.; Hadri, L. Pulmonary Artery Hypertension Model in Rats by Monocrotaline Administration. Methods Mol. Biol. 2018, 1816, 233-241. [PubMed]

64. Taraseviciene-Stewart, L.; Kasahara, Y.; Alger, L.; Hirth, P.; Mc Mahon, G.; Waltenberger, J.; Voelkel, N.F.; Tuder, R.M. Inhibition of the VEGF receptor 2 combined with chronic hypoxia causes cell death-dependent pulmonary endothelial cell proliferation and severe pulmonary hypertension. FASEB J. 2001, 15, 427-438. [CrossRef]

65. Maarman, G.; Lecour, S.; Butrous, G.; Thienemann, F.; Sliwa, K. A comprehensive review: The evolution of animal models in pulmonary hypertension research; are we there yet? Pulm. Circ. 2013, 3, 739-756. [CrossRef] [PubMed]

66. Dupuis, J.; Weissmann, N. Animal Models of Pulmonary Hypertension. In Textbook of Pulmonary Vascular Disease; Yuan, J.J., Garcia, J., West, J., Hales, C., Rich, S., Archer, S., Eds.; Springer: Boston, MA, USA, 2011.

67. Kim, J.; Hwangbo, C.; Hu, X.; Kang, Y.; Papangeli, I.; Mehrotra, D.; Park, H.; Ju, H.; McLean, D.L.; Comhair, S.A.; et al. Restoration of impaired endothelial myocyte enhancer factor 2 function rescues pulmonary arterial hypertension. Circulation 2015, 131, 190-199. [CrossRef]

68. Billaud, M.; Dahan, D.; Marthan, R.; Savineau, J.P.; Guibert, C. Role of the gap junctions in the contractile response to agonists in pulmonary artery from two rat models of pulmonary hypertension. Respir. Res. 2011, 12, 30. [CrossRef]

69. Yang, L.; Yin, N.; Hu, L.; Fan, H.; Yu, D.; Zhang, W.; Wang, S.; Feng, Y.; Fan, C.; Cao, F.; et al. Sildenefil increases connexin 40 in smooth muscle cells through activation of BMP pathways in pulmonary arterial hypertension. Int. J. Clin. Exp. Pathol. 2014, 7, 4674-4684.

70. Bouvard, C.; Genet, N.; Phan, C.; Rode, B.; Thuillet, R.; Tu, L.; Robillard, P.; Campagnac, M.; Soleti, R.; Dumas De La Roque, E.; et al. Connexin-43 is a promising target for pulmonary hypertension due to hypoxaemic lung disease. Eur. Respir. J. 2020, 55, 1900169. [CrossRef]

71. Mondejar-Parreño, G.; Callejo, M.; Barreira, B.; Morales-Cano, D.; Esquivel-Ruiz, S.; Filice, M.; Moreno, L.; Cogolludo, A.; Perez-Vizcaino, F. miR-1 induces endothelial dysfunction in rat pulmonary arteries. J. Physiol. Biochem. 2019, 75, 519-529. [CrossRef]

72. McNair, A.J.; Wilson, K.S.; Martin, P.E.; Welsh, D.J.; Dempsie, Y. Connexin 43 plays a role in proliferation and migration of pulmonary arterial fibroblasts in response to hypoxia. Pulm. Circ. 2020, 10, 2045894020937134. [CrossRef] [PubMed]

73. Ryan, J.J.; Archer, S.L. The right ventricle in pulmonary arterial hypertension: Disorders of metabolism, angiogenesis and adrenergic signaling in right ventricular failure. Circ. Res. 2014, 115, 176-188. [CrossRef] [PubMed]

74. Strauss, B.; Sassi, Y.; Bueno-Beti, C.; Ilkan, Z.; Raad, N.; Cacheux, M.; Bisserier, M.; Turnbull, I.C.; Kohlbrenner, E.; Hajjar, R.J.; et al. Intra-tracheal gene delivery of aerosolized SERCA2a to the lung suppresses ventricular arrhythmias in a model of pulmonary arterial hypertension. J. Mol. Cell. Cardiol. 2019, 127, 20-30. [CrossRef] [PubMed]

75. Kharin, S.N.; Krandycheva, V.V.; Tsvetkova, A.S.; Shumikhin, K.V. Remodeling of ventricular repolarization in experimental right ventricular hypertrophy. J. Electrocardiol. 2017, 50, 626-633. [CrossRef] 
76. Temple, I.P.; Logantha, S.J.; Absi, M.; Zhang, Y.; Pervolaraki, E.; Yanni, J.; Atkinson, A.; Petkova, M.; Quigley, G.M.; Castro, S.; et al. Atrioventricular Node Dysfunction and Ion Channel Transcriptome in Pulmonary Hypertension. Circulation 2016, 9, e003432. [CrossRef]

77. Hiram, R.; Naud, P.; Xiong, F.; Al-U'datt, D.; Algalarrondo, V.; Sirois, M.G.; Tanguay, J.F.; Tardif, J.C.; Nattel, S. Right Atrial Mechanisms of Atrial Fibrillation in a Rat Model of Right Heart Disease. J. Am. Coll. Cardiol. 2019, 74, 1332-1347. [CrossRef]

78. Szeiffova Bacova, B.; Viczenczova, C.; Andelova, K.; Sykora, M.; Chaudagar, K.; Barancik, M.; Adamcova, M.; Knezl, V.; Egan Benova, T.; Weismann, P.; et al. Antiarrhythmic Effects of Melatonin and Omega-3 Are Linked with Protection of Myocardial Cx43 Topology and Suppression of Fibrosis in Catecholamine Stressed Normotensive and Hypertensive Rats. Antioxidants 2020, 9, 546. [CrossRef]

79. Fontes, M.S.; van Veen, T.A.; de Bakker, J.M.; van Rijen, H.V. Functional consequences of abnormal Cx43 expression in the heart. Biochim. Biophys. Acta 2012, 1818, 2020-2029. [CrossRef]

80. Lucero, C.M.; Andrade, D.C.; Toledo, C.; Díaz, H.S.; Pereyra, K.V.; Diaz-Jara, E.; Schwarz, K.G.; Marcus, N.J.; Retamal, M.A.; Quintanilla, R.A.; et al. Cardiac remodeling and arrhythmogenesis are ameliorated by administration of Cx43 mimetic peptide Gap27 in heart failure rats. Sci. Rep. 2020, 10, 6878. [CrossRef]

81. Ahmed, L.A.; Rizk, S.M.; El-Maraghy, S.A. Pinocembrin ex vivo preconditioning improves the therapeutic efficacy of endothelial progenitor cells in monocrotaline-induced pulmonary hypertension in rats. Biochem. Pharmacol. 2017, 138, 193-204. [CrossRef]

82. Tanaka, Y.; Takase, B.; Yao, T.; Ishihara, M. Right ventricular electrical remodeling and arrhythmogenic substrate in rat pulmonary hypertension. Am. J. Respir. Cell Mol. Biol. 2013, 49, 426-436. [CrossRef] [PubMed]

83. Sun, C.K.; Yuen, C.M.; Kao, Y.H.; Chang, L.T.; Chua, S.; Sheu, J.J.; Yen, C.H.; Ko, S.F.; Yip, H.K. Propylthiouracil attenuates monocrotaline-induced pulmonary arterial hypertension in rats. Circ. J. 2009, 73, 1722-1730. [CrossRef] [PubMed]

84. Lee, F.Y.; Lu, H.I.; Zhen, Y.Y.; Leu, S.; Chen, Y.L.; Tsai, T.H.; Chung, S.Y.; Chua, S.; Sheu, J.J.; Hsu, S.Y.; et al. Benefit of combined therapy with nicorandil and colchicine in preventing monocrotaline-induced rat pulmonary arterial hypertension. Eur. J. Pharm. Sci. 2013, 50, 372-384. [CrossRef] [PubMed]

85. Yen, C.H.; Tsai, T.H.; Leu, S.; Chen, Y.L.; Chang, L.T.; Chai, H.T.; Chung, S.Y.; Chua, S.; Tsai, C.Y.; Chang, H.W.; et al. Sildenafil improves long-term effect of endothelial progenitor cell-based treatment for monocrotaline-induced rat pulmonary arterial hypertension. Cytotherapy 2013, 15, 209-223. [CrossRef] [PubMed]

86. Chang, L.T.; Sun, C.K.; Sheu, J.J.; Chiang, C.H.; Youssef, A.A.; Lee, F.Y.; Wu, C.J.; Yip, H.K. Cilostazol therapy attenuates monocrotaline-induced pulmonary arterial hypertension in rat model. Circ. J. 2008, 72, 825-831. [CrossRef] [PubMed]

87. Hardziyenka, M.; Campian, M.E.; Verkerk, A.O.; Surie, S.; van Ginneken, A.C.; Hakim, S.; Linnenbank, A.C.; de Bruin-Bon, H.A.; Beekman, L.; van der Plas, M.N.; et al. Electrophysiologic remodeling of the left ventricle in pressure overload-induced right ventricular failure. J. Am. Coll. Cardiol. 2012, 59, 2193-2202. [CrossRef] [PubMed]

88. Sasano, C.; Honjo, H.; Takagishi, Y.; Uzzaman, M.; Emdad, L.; Shimizu, A.; Murata, Y.; Kamiya, K.; Kodama, I. Internalization and dephosphorylation of connexin43 in hypertrophied right ventricles of rats with pulmonary hypertension. Circ. J. 2007, 71, 382-389. [CrossRef]

89. Uzzaman, M.; Honjo, H.; Takagishi, Y.; Emdad, L.; Magee, A.I.; Severs, N.J.; Kodama, I. Remodeling of gap junctional coupling in hypertrophied right ventricles of rats with monocrotaline-induced pulmonary hypertension. Circ. Res. 2000, 86, 871-878. [CrossRef]

90. Tan, X.Y.; He, J.G. The remodeling of connexin in the hypertrophied right ventricular in pulmonary arterial hypertension and the effect of a dual ET receptor antagonist (bosentan). Pathol. Res. Pract. 2009, 205, 473-482. [CrossRef]

91. Montgomery, M.O.; Jiao, Y.; Phillips, S.J.; Singh, G.; Xu, J.; Balsara, R.; Litvin, J. Alterations in sheep fetal right ventricular tissue with induced hemodynamic pressure overload. Basic Res. Cardiol. 1998, 93, 192-200. [CrossRef]

92. Johnson, J.A.; West, J.; Maynard, K.B.; Hemnes, A.R. ACE2 improves right ventricular function in a pressure overload model. PLoS ONE 2011, 6, e20828. [CrossRef] [PubMed]

93. Kusakari, Y.; Urashima, T.; Shimura, D.; Amemiya, E.; Miyasaka, G.; Yokota, S.; Fujimoto, Y.; Akaike, T.; Inoue, T.; Minamisawa, S. Impairment of Excitation-Contraction Coupling in Right Ventricular Hypertrophied Muscle with Fibrosis Induced by Pulmonary Artery Banding. PLoS ONE 2017, 12, e0169564. [CrossRef] [PubMed]

94. Chkourko, H.S.; Guerrero-Serna, G.; Lin, X.; Darwish, N.; Pohlmann, J.R.; Cook, K.E.; Martens, J.R.; Rothenberg, E.; Musa, H.; Delmar, M. Remodeling of mechanical junctions and of microtubule-associated proteins accompany cardiac connexin43 lateralization. Heart Rhythm 2012, 9, 1133-1140.e6. [CrossRef] [PubMed]

95. Schultz, J.G.; Andersen, S.; Andersen, A.; Erik Nielsen-Kudsk, J.; Nielsen, J.M. Evaluation of cardiac electrophysiological properties in an experimental model of right ventricular hypertrophy and failure. Cardiol. Young 2016, 26, 451-458. [CrossRef]

96. Ferreira, A.J.; Shenoy, V.; Yamazato, Y.; Sriramula, S.; Francis, J.; Yuan, L.; Castellano, R.K.; Ostrov, D.A.; Oh, S.P.; Katovich, M.J.; et al. Evidence for angiotensin-converting enzyme 2 as a therapeutic target for the prevention of pulmonary hypertension. Am. $J$. Respir. Crit. Care Med. 2009, 179, 1048-1054. [CrossRef]

97. Hemnes, A.R.; Rathinasabapathy, A.; Austin, E.A.; Brittain, E.L.; Carrier, E.J.; Chen, X.; Fessel, J.P.; Fike, C.D.; Fong, P.; Fortune, N.; et al. A potential therapeutic role for angiotensin-converting enzyme 2 in human pulmonary arterial hypertension. Eur. Respir. J. 2018, 51, 1702638. [CrossRef] 
98. Channick, R.N.; Simonneau, G.; Sitbon, O.; Robbins, I.M.; Frost, A.; Tapson, V.F.; Badesch, D.B.; Roux, S.; Rainisio, M.; Bodin, F.; et al. Effects of the dual endothelin-receptor antagonist bosentan in patients with pulmonary hypertension: A randomised placebo-controlled study. Lancet 2001, 358, 1119-1123. [CrossRef]

99. Maki, H.; Hara, T.; Tsuji, M.; Saito, A.; Minatsuki, S.; Inaba, T.; Amiya, E.; Hosoya, Y.; Hatano, M.; Morita, H.; et al. The Clinical Efficacy of Endothelin Receptor Antagonists in Patients with Pulmonary Arterial Hypertension. Int. Heart J. 2020, 61, 799-805. [CrossRef]

100. Zhang, L.; Fan, Z.R.; Wang, L.; Liu, L.Q.; Li, X.Z.; Li, L.; Si, J.Q.; Ma, K.T. Carbenoxolone decreases monocrotaline-induced pulmonary inflammation and pulmonary arteriolar remodeling in rats by decreasing the expression of connexins in $\mathrm{T}$ lymphocytes. Int. J. Mol. Med. 2020, 45, 81-92. [CrossRef] 